\title{
Analisis Bauran Pemasaran dalam Pengembangan Layanan Private Wing di Rumah Sakit Nasional Diponegoro
}

\author{
Muhammad Farras Razin Perdana ${ }^{1}$, Sutopo Patria Jati ${ }^{2}$, Septo Pawelas Arso ${ }^{3}$ \\ ${ }^{\text {I} P r o g r a m ~ S t u d i ~ M a g i s t e r ~ K e s e h a t a n ~ M a s y a r a k a t ~ F a k u l t a s ~ K e s e h a t a n ~ M a y a r a k a t, ~ U n i v e r s i t a s ~ D i p o n e g o r o, ~ J l ~ P r o f ~ S u d a r t o, ~}$ \\ Semarang, 50275 \\ E-mail: muhammadfarras395@students.undip.ac.id \\ ${ }^{2}$ Program Studi Magister Kesehatan Masyarakat Fakultas Kesehatan Mayarakat, Universitas Diponegoro, Jl Prof Sudarto, \\ Semarang, 50275 \\ E-mail: sutopopatriajati@lecturer.undip.ac.id \\ ${ }^{3}$ Program Studi Magister Kesehatan Masyarakat Fakultas Kesehatan Mayarakat, Universitas Diponegoro, Jl Prof Sudarto, \\ Semarang, 50275 \\ E-mail: septoarso@lecturer.undip.ac.id
}

\begin{abstract}
The hospital is one of the businesses engaged in the health sector by emphasizing the products and health facilities that are able to be provided by the hospital. Considering the high level of competition in hospitals in Indonesia, both state-owned and private hospitals, many hospitals have developed marketing strategies to meet sales targets and realize marketing goals. One of them is the Diponegoro National Hospital which runs a Global Innovative Marketing strategy by providing exclusive Private Wing services for special customers or VIPs (Very Important Person). In this case, the researcher reviews the marketing mix of Private Wings Services through seven variables, namely product, price, place, physical evidence, people, promotion, process. The process of collecting data was carried out by in-depth interview techniques and literature studies on several related literatures that were used as research references. The research was conducted qualitatively and the data that had been collected were analyzed descriptively. The results of this study indicate that the promotion and place variables need to be a concern for the Diponegoro National Hospital in developing Private Wing services.
\end{abstract}

Keywords — : Mix Marketing, Private Wing, Rumah Sakit Nasional Diponegoro

\section{PENDAHULUAN}

\section{A. Latar Belakang}

Masyarakat memiliki kebutuhan dan tuntutan terhadap pelayanan kesehatan yang optimal. Fenomena ini menuntut fasilitas pelayanan kesehatan bergerak memperbaiki diri untuk memberikan pelayanan optimal (Pujiyanto, 2012). Selain itu, dalam zaman globalisasi ini, layanan kesehatan suidah bergeser dalam tujuan pemberian layanan. Dahulu, layanan kesehatan bersifat non-profit, namun tidak dipungkiri bahwa profit dibutuhkan dalam pengembangan layanan kesehatan hingga memberikan kesejahteraan bagi tenaga kesehatan.

Rumah Sakit adalah institusi pelayanan kesehatan yang melaksanakan pelayanan kesehatan perorangan secara paripurna yang menyediakan pelayanan rawat inap, rawat jalan dan gawat darurat. Layanan rumah sakit yang baik dapat meningkatkan outcome berupa peningkatan kepercayaan publik terhadap rumah sakit. Kepercayaan publik yang meningkat, berpotensi menambah income pada rumah sakit (Undang-Undang Republik Indonesia Nomor 44 Tahun 2009 Tentang Rumah Sakit, 2009).

Biaya pengelolaan rumah sakit pemerintah tidak dapat hanya mengandalkan anggaran pemerintah. Indonesia saat ini menerapkan JKN, akan tetapi proses pembayaran klaim BPJS seringkali mengalami keterlambatan (Pratami et al., 2016). Di sisi lain, adanya penyakit COVID-19 di Indonesia juga menjadi tantangan bagi rumah sakit untuk bersiap mengaktifkan kembali prosedur kebencanaannya.

Rumah sakit publik menangkap sebuah peluang untuk mendirikan sebuah paviliun swasta, yaitu ruangan rawat inap ataupun poliklinik yang dilengkapi dengan sarana yang sangat memadai dan pasien dipungut bayaran seperti rumah sakit swasta (MedPAC, 2018). Kementerian Kesehatan Indonesia kemudian mengeluarkan Peraturan Menteri Kesehatan Nomor 11 Tahun 2016 tentang Penyelenggaraan Pelayanan Rawat Jalan Eksekutif di Rumah Sakit. Keberadaan ruang perawatan eksekutif tersebut selain memberikan pemasukan yang riil kepada rumah sakit juga dapat memotivasi tenaga kesehatan untuk memberikan kinerja yang terbaik karena tidak terbatas adanya plafon INA-CBGs dalam memberikan pengobatan.

Pelayanan yang tidak terbatas pada plafon dapat menaikkan kualitas pelayanan. Kualitas pelayanan yang baik merupakan salah satu faktor yang menonjol agar pasien mau berkunjung dan memanfatkan fasilitas rawat jalan serta menciptakan loyalitas terhadap rumah sakit itu sendiri. Loyalitas merupakan kunci penting dalam rumah sakit memenangi persaingan dengan rumah sakit competitor (Guinane \& Davis, 2012). 
Website : http://ekomaks.unmermadiun.ac.id/index.php/ekomaks

Rumah sakit perlu memikirkan strategi dalam menangkap pasar layanan yang ditawarkan. Strategi yang baik adalah strategi yang dapat mendukung pemasaran produk jasa layanan yang mampu meningkatkan kepuasan pelanggan menggunakan Buaran pemasaran (Sibarani \& Riani, 2017). Bauran Pemasaran (Marketing Mix) adalah seperangkat variable-variable pemasaran yang digabungkan dalam rangkia mendapatkan tanggapan yang tepat dari produk yang dipasarkan. Dengan Marketing Mix, pihak rumah sakit akan dapat mengembangkan kegiatan pemasaran lebih luas dan spesifik untuk rumah sakit karena lebih rinci, upaya yang dilakukan akan lebih jelas dan terarah.

Manajemen pemasaran di Rumah Sakit, adalah upaya dalam menaikkan utilisasi pelayanan rumah sakit menjadi lebih tinggi. Hal ini, sejalan dengan misi Rumah Sakit Nasional Diponegoro dalam menaikkan utilisasi rawat jalan yang masih rendah, terutama dalam melayani pasien umum. Manajemen pemasaran adalah media pengenalan sehingga lebih banyak masyarakat yang datang berobat ke rumah sakit.

Rumah Sakit Nasional Diponegoro (RSND) adalah rumah sakit pendidikan di lingkungan Fakultas Kedokteran Universitas Diponegoro. RSND memiliki Bangsal kelas III, II, I hingga VIP. Rata-rata Bed Occupancy Rate (BOR) di RSND pada tahun 2019 sebesar 34,54\%. Angka BOR yang rendah ini tentu akan menyulitkan RSND dalam tumbuh dan berkembang. Selain itu, kepuasan pelanggan di Instalasi Rawat Jalan belum mencapai standar minimal yakni 80\%. Hampir seluruh aspek masih perlu ditingkatkan dan ditemukan bahwa sebanyak $30 \%$ pasien mengeluhkan jam pelayanan yang hanya tersedia di pagi hari sehingga membuat mereka perlu menyesuaikan dengan aktivitas pasien. RSND dalam menanggapi hal tersebut berencana melakukan pengembangan ruang rawat jalan eksekutif yang dinamakan Private Wing.

Dalam rangka pembuatan private wing, Rumah Sakit Nasional diponegoro perlu melakukan kajian bauran pemasaran sebelum dibukanya private wing di RSND. Private wing bersifat optimalisasi dari poliklinik regular yang sudah berjalan di pagi hari. Sehingga peneliti melakukan observasi pada pelaksanaan poliklinik regular.

\section{B. Perumusan Masalah}

Penelitian ini akan meninjau bauran pemasaran (marketing mix) dalam pengembangan layanan Private Wing di Rumah Sakit Nasional Diponegoro.

1. Bagaimana analisis bauran pemasaran product terhadap pengembangan layanan Private Wing di Rumah Sakit Nasional Diponegoro?

2. Bagaimana analisis bauran pemasaran price terhadap pengembangan layanan Private Wing di Rumah Sakit Nasional Diponegoro?

3. Bagaimana analisis bauran pemasaran place terhadap pengembangan layanan Private Wing di Rumah Sakit Nasional Diponegoro?

4. Bagaimana analisis bauran pemasaran physical evidence terhadap pengembangan layanan Private Wing di Rumah Sakit Nasional Diponegoro?

5. Bagaimana analisis bauran pemasaran people terhadap pengembangan layanan Private Wing di Rumah Sakit Nasional Diponegoro?

6. Bagaimana analisis bauran pemasaran promotion terhadap pengembangan layanan Private Wing di Rumah Sakit Nasional Diponegoro?

7. Bagaimana analisis bauran pemasaran process terhadap pengembangan layanan Private Wing di Rumah Sakit Nasional Diponegoro?

\section{Tujuan Penelitian}

Berdasarkan perumusan masalah di atas, dapat diketahui bahwa penelitian ini bertujuan untuk:

1. Untuk menganalisis bauran pemasaran product terhadap pengembangan layanan Private Wing di Rumah Sakit Nasional Diponegoro.

2. Bagaimana analisis bauran pemasaran price terhadap pengembangan layanan Private Wing di Rumah Sakit Nasional Diponegoro.

3. Bagaimana analisis bauran pemasaran place terhadap pengembangan layanan Private Wing di Rumah Sakit Nasional Diponegoro.

4. Bagaimana analisis bauran pemasaran physical evidence terhadap pengembangan layanan Private Wing di Rumah Sakit Nasional Diponegoro.

5. Bagaimana analisis bauran pemasaran people terhadap pengembangan layanan Private Wing di Rumah Sakit Nasional Diponegoro.

6. Bagaimana analisis bauran pemasaran promotion terhadap pengembangan layanan Private Wing di Rumah Sakit Nasional Diponegoro.

7. Bagaimana analisis bauran pemasaran process terhadap pengembangan layanan Private Wing di Rumah Sakit Nasional Diponegoro. 
Website : http://ekomaks.unmermadiun.ac.id/index.php/ekomaks

\section{TINJAUAN TEORITIS}

\section{A. Bauran Pemasaran}

Kotler dalam Thabit \& Raewf (2018) mendefiniskan bauran pemasaran atau dikenal sebagai marketing mix sebagai kelompok variabel yang dapat dikendalikan dan digunakan oleh organisasi untuk mempengaruhi respon pembeli terhadap produk atau jasa. Sementara itu CIM dalam Thabit \& Raewf (2018) menyebutkan bahwa bauran pemasaran merupakan kombinasi yang digunakan oleh bisnis untuk mewujudkan tujuannya dengan memasarkan produknya atau jasa secara efektif kepada kelompok pelanggan sasaran tertentu. Berdasarkan dua pendapat tersebut, dapat disimpulkan bahwa bauran pemasaran merupakan kombinasi dari berbagai variabel keputusan pemasaran, strategi, dan taktik yang digunakan oleh manajemen suatu organisasi atau perusahaan untuk memasarkan barang dan/atau jasanya.

Variabel yang dikombinasikan tersebut meliputi 7P, yakni product, price, place, physical evidence, people, promotion, dan process. Konsep bauran pemasaran adalah melakukan tindakan yang saling terkait untuk menghasilkan solusi guna memenuhi kebutuhan konsumen dan mencapai tujuan pemasaran perusahaan secara keseluruhan (Išoraitė, 2016).

Berikut penjabaran mengenai $7 \mathrm{P}$ yang terdapat pada bauran pemasaran.

1. Product adalah upaya pemasaran yang berkaitan dengan segala sesuatu yang ditawarkan untuk memenuhi konsumen kebutuhan. Bauran produk terdiri dari jenis produk, kualitas, desain, kelengkapan, merek nama, kemasan, ukuran, layanan produk, garansi dan penggantian (Kukanja et al., 2017).

2. Price adalah elemen bauran pemasaran dari berapa banyak uang yang dibelanjakan konsumen untuk membeli produk untuk memenuhi kebutuhan mereka dan keinginan. Pada tingkat harga tertentu, jika manfaat yang dirasakan konsumen meningkat, maka nilainya akan meningkat sebagai baik (Anjani et al., 2018).

3. Place adalah lokasi atau area pasar tempat pedagang menjual atau mendistribusikan barang dagangannya sehingga tersedia untuk konsumen. Kushwaha dan Agrawal (2015) menjelaskan bahwa keputusan untuk distribusi fisik mempertimbangkan urutan prosesnya, letak penyimpanannya, kesiapannya, dan bagaimana barang harus diangkut.

4. Phisycal evidence berfokus pada kondisi fisik di tempat bisnis termasuk sekitarnya daerah (Dr. Muhammad Tariq Khan, 2014). Bukti fisik elemen pemasaran termasuk lingkungan pendukung (perabotan, warna, tata letak, tingkat kebisingan), mendukung barang, tata ruang, kebersihan dan peralatan, fasilitas penunjang seperti toilet, masjid dan tempat parkir (Kukanja et al., 2017).

5. People dapat didefinisikan sebagai peran manusia dalam penyampaiannya barang atau jasa yang dapat mempengaruhi persepsi konsumen (Kukanja et al., 2017). Menurut Kushwaha dan Agrawal (2015), berorientasi pada pelanggan karyawan fokus untuk menunjukkan pribadi perhatian, perawatan interpersonal, kesopanan dan perilaku cepat.

6. Promotion adalah upaya untuk menyampaikan informasi atau untuk berkomunikasi antara pedagang dan konsumen dengan tujuan menyebarkan informasi, mempengaruhi, membujuk, dan mengingatkan target pasar untuk menciptakan permintaan akan produk atau jasa yang ditawarkan oleh pedagang (Marques et al., 2014).

7. Process menjelaskan metode dan urutan dalam layanan dan menciptakan nilai yang dijanjikan kepada pelanggan dengan melayani permintaan setiap pelanggan (Kushwaha \& Agrawal, 2015). Elemen proses termasuk fasilitas dalam jual beli, dan cepat tanggapan penjual untuk memenuhi permintaan konsumen, respons tangkas terhadap keluhan konsumen atas produk dan layanan (Yarimoglu, 2014).

Berdasarkan uraian di atas, dapat dipahami bahwa bauran pemasaran (mix marketing) merupakan salah satu strategi pemasaran dengan mengkombinasikan tujuh variabel di atas (7P) yang bertujuan untuk membangun merek (branding) serta memenuhi targer penjualan sebagai langkah mewujudkan tujuan pemasaran.

\section{B. Layanan Private Wing}

Layanan Private Wing merupakan unit pelayanan privat dan perawatan kesehatan eksklusif yang memberikan akses terhadap pelayanan kesehatan inovatif. Adapun pelayanan yang dimaksud berupa antar jemput pasien di berbagai tempat, seperti bandara. Selain itu International Costumer Service dengan sigap melayani pelanggan Private Wing yang turut mempermudah proses registrasi dan administrasi selama pelanggan Private Wing berada di rumah sakit tersebut. Homestay bagi keluarga pelanggan Private Wing juga telah disiapkan oleh rumah sakit baik bagi pasien dari luar kota hingga luar negeri.

Munculnya layanan Private Wing merupakan salah satu langkah rumah sakit di Indonesia menerapkan strategi Global Innovative Marketing dengan didukung oleh sumber daya manusia (SDM) profesional yang mampu memfasilitasi inovasi pelayanan yang digaungkan oleh rumah sakit (Widajat, 2021). Berikut beberapa layanan private wing yang kerap ditemukan di rumah sakit Indonesia.

\begin{tabular}{cll}
\hline & \multicolumn{1}{c}{ Tabel 1. Fasilitas Private Wing di Indonesia } \\
\hline No & \multicolumn{1}{c}{ Fasilitas } & \multicolumn{1}{c}{ Keterangan } \\
\hline 1 & Kemudahan registrasi & Proses pendaftaran dipermudah tanpa adanya antrian \\
2 & Kemudahan administrasi & Berkas pendaftaran tidak terlalu rumit dibandingkan pasien pada umumnya \\
3 & Antar jemput pasien & Piahk rumah sakit menyiapkan transportasi khusus untuk menyediakan \\
& & layanan antar dan jemput bagi pasien Private Wing \\
4 & Homestay keluarga pasien & Keluarga pasien dapat dengan nyaman berada di sekitar rumah sakit dengan \\
& & menggunakan homestay yang telah disiapkan \\
5 & International Costumer Service & Peleanggan yang berasal dari luar negeri dapat berkomunikasi dengan baik \\
& dan nyaman melalui International Costumer Service
\end{tabular}


Website : http://ekomaks.unmermadiun.ac.id/index.php/ekomaks

\section{Penelitian Terdahulu}

1. Penelitian pertama berangkat dari Christian A.D. Selang dengan judul "Bauran Pemasaran (Marketing Mux) Pengaruhnya terhadap Loyalitas Konsumen pada Fresh Mart Bahu Mall Manado. Penelitian dilakukan secara kuantitafi dengan menguji variabel bauran pemasaran dengan variabel loyalitas konsumen. Hasil penelitian ini menunjukkan bahwa variabel produk, promosi, dan tempat berpengarug secara signidikan terhadap loyalitas konsumen di Fresh Mart Bahu Mall Manado (Selang, 2016)

2. Penelitian yang kedua berjudul "Strategi Bauran Pemasaran (Marketing Mix Strategy) di Pasarkita Pamulang" oleh Arie Putra Benyamin pada tahun 2019. Penelitian ini dilakukan secara kualitatif dengan melakukan wawancara, studi lapangan, dan studi pustaka sebagai metode pengumpulan data. Hasil penelitian ini menyebutkan bahwa variabel produk, harga, tempat dan promosi masih terbatas dab dinilai kurang kompetitif berdasarkan kualitas (Benyamin, 2019).

3. Penelitian selanjutnya dilakukan oleh Muhammad Fauzan abdurrahman, Arief Daryanto, dan Ani Nuraisyah pada tahun 2021 dengan judul "Coffee to Go Marketing Mix (7P) Analysis to Improve Customer Satisfaction (Case Study Katuhu Coffee). Penelitian ini dilakukan menggunakan pendekatan kuantitatif dan mengahbiskan waktu satu bulan lamanya dalam proses penelitian. Hasil penelitian menunjukkan bahwa variabel produk memiliki nilai yang kuat karena adanya varian menu yang inovatif (Abdurrahman et al., 2021).

\section{METODE PENELITIAN}

Desain penelitian yang digunakan adalah studi kasus dengan pendekatan kualitatif menggunakan pendekatan deskriptif analitik. Penelitian kualitatif merupakan penelitian yang dilakukan dengan menggunakan pendekatan interpretatif yang mencoba untuk mendapatkan wawasan tentang makna dan perilaku tertentu yang dialami dalam fenomena sosial tertentu melalui pengalaman subjektif para partisipan. Peneliti membangun abstrak, konsep, hipotesis, atau teori dengan mengajukan pertanyaan seperti "mengapa", "bagaimana" dan "dengan cara apa?". Tujuannya adalah untuk memahami fenomena dari sudut pandang partisipan dengan konteks kelembagaan dan sosial tertentu yang utuh serta data dan konteks ini hilang jika upaya untuk mengukur data dilakukan. Validitas metode kualitatif dapat ditingkatkan dengan menggunakan kombinasi metode pengumpulan data (suatu proses yang dikenal sebagai triangulasi) dan dengan analisis data oleh lebih dari satu orang (Palmer \& Bolderston, 2006).

Data tentang aspek pasar dikumpulkan melalui teknik wawancara mendalam (in-depth interview) pada informan utama maupun informan triangulasi. Wawancara merupakan metode penelitian kualitatif yang penting di mana peneliti mengumpulkan data langsung dari partisipan. Sebagian besar dipasangkan dengan metode penelitian lain seperti survei, focus group, dll., wawancara sangat penting dalam mengungkapkan pendapat, pengalaman, nilai, dan berbagai aspek lain dari populasi yang diteliti. Wawancara selalu berorientasi pada tujuan. Wawancara mendalam (in depth interview) sebagian besar berdurasi panjang dan dilakukan secara tatap muka, wawancara yang dilakukan bertujuan untuk menjawab pertanyaan atau perumusan masalah dari peneliti. Wawancara mendalam juga dikenal sebagai satu-satu adalah metode penggalian informasi yang lebih rinci atau pemahaman yang mendalam tentang subjek atau konsep (Showkat \& Parveen, 2017).

Responden yang dijadikan sebagai informan utama adalah para direktur dan manajer rumah sakit. Untuk menguji validitas data, dipilih informan triangulasi yaitu dokter-dokter spesialis RSND dan 15 pasien rawat jalan regular RSND dengan pembiayaan umum atau asuransi selain BPJS.

Teknik pengumpulan data primer dilakukan melalui field research (penelitian lingkungan) pada bulan Januari 2021 hingga Juni 2021 atau selama kurang lebih 6 bulan di Rumah Sakit Nasional Diponegoro yang berlokasi di Jalan Prof. Soedarto, SH., Tembalang, Semarang. Pengumpulan data sekunder dilakukan dengan cara telaah dokumen data-data yang terkait baik melalui artikel, berita, hingga undang-undang. Adapun konsep pengukuran variabel yang digunakan beracuan pada cakupan tujuh variabel dalam analisis bauran pemasaran yang akan dijelaskan pada tabel di bawah ini.

Tabel 2. Ukuran Tujuh Variabel Bauran Pemasaran
\begin{tabular}{|c|l|l|}
\hline No & \multicolumn{1}{|c|}{ Variabel } & \multicolumn{1}{c|}{ Ukuran } \\
\hline 1 & Product (Produk) & $\begin{array}{l}\text { Ciri fisik produk (tampilan, kreasi, kemasan, merek, rasa atau } \\
\text { pengalaman }\end{array}$ \\
\hline 2 & Price (Harga) & Harga jual dan strategi penetapan harga \\
\hline 3 & Place (Tempat) & Lokasi, akses, tinjaun sifat kondusif/strategis \\
\hline 4 & Phisycal Evidence (Bukti Fisik) & $\begin{array}{l}\text { Sarana dan prasarana, kualitas pelayanan, spesifikasi saranan dan } \\
\text { prasarana (simbol, seragam, warna, corak) }\end{array}$ \\
\hline 5 & People (Orang) & Kinerja karyawan (SDM) dan pelanggan \\
\hline 6 & Promotion (Promosi) & $\begin{array}{l}\text { Kegiatan pemasaran untuk pengenalan produk (iklan, penjualan pribadi, } \\
\text { hubungan masyarakat, promosi penjualan) }\end{array}$ \\
\hline 7 & Process (Proses) & Prosedur pembelian barang/berlangganan/penggunaan jasa \\
\hline
\end{tabular}
Sumber: (Nugroho \& Japarianto, 2013)


Website : http://ekomaks.unmermadiun.ac.id/index.php/ekomaks

\section{IV.ANALISIS DAN PEMBAHASAN}

Dalam penelitian ini, peneliti meninjau tujuh variabel bauran pemasaran Rumah Sakit Nasionak Diponegoro terhadap strategi pemasaran Pelayanan Private Wing yang disediakan oleh Rumah Sakit Nasional Diponegoro. Berikut penjabaran mengenai tujuh variabel yang dimaksud.

Tabel 3. Tujuh Variabel Bauran Pemasaran di Rumah Sakit Nasional Diponegoro

\begin{tabular}{cll}
\hline No & \multicolumn{1}{c}{ Variabel } & \multicolumn{1}{c}{ RSND } \\
\hline 1 & Product (Produk) & Klinik eksekutif one stop service \\
2 & Price (Harga) & Mekanismem pembayaran out of pocket \\
3 & Place (Tempat) & Akses lokasi rumah sakit sulit \\
4 & Phisycal Evidence (Bukti Fisik) & Desain rumah sakit yang modern dan minimalis \\
5 & People (Orang) & Tenaga kerja mencakup sebagai dosen \\
6 & Promotion (Promosi) & WOM (Word of Mouth) \\
7 & Process (Proses) & Prosedur registrasi dan administrasi \\
\hline \multicolumn{2}{l}{ Sumber: Observasi Peneliti }
\end{tabular}

\section{A. Analisis Bauran Pemasaran Product (Produk)}

Produk dalam penelitian ini adalah pelayanan klinik eksekutif yang bersifat one stop service. Klinik Eksekutif adalah optimalisasi produk yang sudah berjalan, dikemas berbeda dengan pelayanan yang selama ini ada di RS Nasional Diponegoro, diharapkan mampu menjadi sarana pendapatan baru, selain itu menjadi alat branding bagi Rumah Sakit Nasional Diponegoro, khususnya dalam menggait pasar pekerja yang beraktivitas pada jam kerja. Perencanaan pada satu tahun awal, akan memaksimalkan klinik rawat jalan yang ada, berdasarkan Permenkes 11 tahun 2016, diferensiasi dapat berupa waktu, yang mana selama satu tahun awal akan memaksimalkan poli rawat jalan regular dengan waktu 15.00-20.00. Produk ini menjadi kebutuhan bagi RS maupun masyarakat disekitar Universitas Diponegoro. RSND harus menjawab tantangan kompetitif dari RS lain, yang memiliki jam praktek dokter diluar jam kerja. Selain itu, masyarakat sangat membutuhkan layanan klinik diluar jam kerja.

\section{B. Analisis Bauran Pemasaran Price (Harga)}

Komponen tarif rawat jalan di RS Nasional Diponegoro terdiri dari tarif jasa dokter dan komponen biaya administrasi. Konsep awal tentang tarif di Klinik Eksekutif adalah tarif jasa dokter dan biaya administrasi lebih tinggi dari klinik reguler.

Pada saat ini, harga pada tarif regular sebesar Rp 80.000,00 - Rp 100.000,00. Dengan tarif sebesar itu, berdasarkan hasil interview dengan pasien, menganggap harga tersebut masih terjangkau, beberapa pasien bersedia apabila dalam poli rawat eksekutif harga dinaikkan menimbang waktu dan kenyamanan.

Selain itu, pada awal pelaksanaan mekanisme pembayaran yang digunakan dalam pelayanan klinik eksekutif adalah mekanisme out of pocket atau penggunaan asuransi swasta. Klinik eksekutif belum menggunakan iur biaya BPJS Kesehatan, hal ini mempertimbangkan ketepatan waktu pembayaran bagi dokter yang hendak mengisi. Untuk pasien yang hendak rawat inap, dapat menggunakan pembiayaan BPJS.

Selain itu, Klinik Eksekutif akan memberikan resultan pendapatan dari pemeriksaan penunjang dan obat rawat jalan. Menurut interview, harga yang ditawarkan masih murah dan DPJP mampu memilih obat yang cenderung murah dan sesuai dengan kemampuan beli dari pasien.

\section{Analisis Bauran Pemasaran Place (Tempat)}

Berdasarkan triangulasi sumber, bahwa informan dari rumah sakit mengatakan bahwa salah satu permasalahan di RSND adalah lokasi yang relative jauh dari pemukiman dan jalan raya. Karena berdasarkan informasi dari pasien didapatkan bahwa susahnya akses menuju ke rumah sakit, mereka mengeluhkan susahnya transportasi menuju rumah sakit. Selain itu, ongkosnya juga terbilang mahal. Terjadi perbedaan pendapat ini disebabkan oleh perbedaan sudut pandang kedua belah pihak informan.

Karena jika dari sudut pandang pihak rumah sakit, rumah sakit sudah berusaha untuk bekerjasama dengan pihak universitas untuk memperbaiki infrastruktur jalan dengan menambah penerangan hingga mengerahkan keamanan untuk memberikan rasa aman. Selain itu, rumah sakit juga akan mengadakan fasilitas shelter untuk memberikan keamanan bagi DPJP maupun pasien. Sehingga pasien dan DPJP tidak khawatir terhadap keamanan.

Sedangkan dari sudut pandang pasien, mereka menilai dari segi kemudahan mereka menuju rumah sakit. Hal ini berkaitan dengan biaya yang akan dikeluarkan oleh pasien ketika menuju rumah sakit. Hal ini sejalan dengan hasil penelitian yang dilakukan yang menyatakan bahwa bagi seorang pasien faktor place berhubungan dengan akses biaya yang mereka keluarkan untuk mendapatkan pelayanan.

Jika dilihat dari faktor saluran distribusi, akses menuju rumah sakit termasuk susah. Meskipun jalan sudah relative baik, namun akses yang berada dibelakang dari Kampus Universitas Diponegoro menimbulkan isu keamanan. Namun jika dilihat dari segi kebisingan, lokasi rumah sakit tidak terlampau bising. Hal ini disebabkan lokasi rumah sakit yang tidak berada di jalan utama dan juga bangunan gedung yang tidak dekat dengan jalan. 
Website : http://ekomaks.unmermadiun.ac.id/index.php/ekomaks

\section{Analisis Bauran Pemasaran Physical Evidence (Bukti Fisik)}

Berdasarkan triangulasi sumber menunjukkan bahwa menurut informan rumah sakit secara keseluruhan rumah sakit memiliki 2 tempat yang dapat dijadikan poliklinik eksekutif. Antara lain merenovasi layanan rawat jalan regular atau bekerja sama dengan FK Universitas Diponegoro dalam memanfaatkan lantai 1 Laboratorium Sentral. Aspek pertama lebih memungkinkan karena hanya optimalisasi dari lahan yang sudah ada. Karena tempat relative dekat dengan laboratorium dan radiologi. Namun menurut permenkes 11 tahun 2016, hal ini tidak dianjurkan karena disarankan sebuah klinik rawat jalan eksekutif harus berbeda ruangan dengan klinik rawat jalan reguler. Hal ini mampu diakomodir oleh opsi 2 yang berbeda gedung dengan opsi 1. Namun, perlu adanya investasi yang harus dilakukan oleh RSND untuk renovasi, pengadaan laboratorium dan instalasi radiologi yang berbeda perlu dilakukan kajian yang matang. Ada banyak aspek yang membuat orang menilai baik suatu fisik rumah sakit. Yang dapat dilihat dari aspek fasilitas penunjang yang dimiliki oleh rumah sakit. Opsi ini akan dipertimbangkan apabila pada satu tahun pertama, pasien yang berobat di poliklinik eksekutif jumlahnya signifikan. Hal ini sesuai dengan teori tampilan fisik bangunan dan berbagai fasilitas penunjang yang dimiliki penyedia jasa berpengaruh pada sikap dan perilaku pelanggan. Oleh karena itu, penyedia jasa perlu memperhatikan bagaimana kondisi bangunan dan fasilitas jasa. Suatu rumah sakit yang tidak memperhatikan tampilan fisik dan fasiltas penunjang akan membuat pasien semakin depresi dan tidak semangat.

Berdasarkan triangulasi metode, yang dikatakan oleh informan pasien memang benar dan sesuai dengan hasil observasi. Dari hasil observasi didapatkan bahwa pihak rumah sakit sudah membuat suatu desain yang berbeda dari tempat lain. Bangunan Rumah Sakit Nasional Diponegoro cukup modern dan minimalis. Sehingga pasien merasa nyaman berada di rumah sakit.

\section{E. Analisis Bauran Pemasaran People (Sumber Daya Manusia)}

Berdasarkan triangulasi sumber menunjukkan bahwa menurut seluruh informan mengatakan bahwa tenaga-tenaga yang disediakan di rumah sakit merupakan tenaga yang profesional dan terlatih sesuai bidang mereka. Sebagai rumah sakit yang diselenggarakan oleh perguruan tinggi negeri, RSND memiliki tenaga mumpuni karena merangkap sebagai dosen. Tentu harapannya memiliki pengalaman klinis yang lebih mumpuni. Sedangkan secara kuantitas, awalan 6 poli spesialis yang dimaksimalkan antara lain Penyakit Dalam, Ilmu Kesehatan Anak, Ilmu Bedah, Obstetri dan Ginekologi, Mata dan THT-KL. Berdasarkan persyaratan klinik eksekutif, persyaratan minimal sumber daya dokter yang ada minimal 3 dokter, dan 6 KSM tersebut sudah memenuhi batas minimal.

RSND masih memiliki permasalahan dalam sistem pemberian jasa medis untuk dokter spesialis yang bertugas. Harapan dari beberapa dokter spesialis, bahwa mereka mendapat guarantee fee dalam bertugas di Private Wing, namun RSND masih mengusahakan terbitnya peraturan rektor yang mengatur fleksibilitas RSND dalam mengatur keuangan.

\section{F. Analisis Bauran Pemasaran Promotion (Promosi)}

Target pasar yang dituju adalah masyarakat umum. Pelaksanaan Private Wing ini menggunakan pembiayaan umum dan asuransi non BPJS. Upaya keras perlu dilakukan karena jumlah pasien yang berobat di RSND dengan pembiayaan tersebut hanya $10 \%$. Selain itu, dari 17 responden in-depth interview didominasi oleh masyarakat yang bekerja di dalam lingkup Universitas Diponegoro. Sehingga tim marketing dan humas perlu melakukan branding yang lebih masif apabila nantinya dibuka Private Wing.

Modal yang sudah dimiliki oleh tim pemasaran antara lain, jejaring dengan FKTP yang terjalin, memaksimalkan relasi dengan word of mouth, harapannya mampu mendatangkan pasien ke Private Wing. Selain itu, adanya kerjasama dengan perusahaan di sekitar RSND dalam rangka mobilisasi karyawan yang bekerja di perusahaan tersebut, dapat menambah jumlah pasien yang akan datang berobat. Selain itu, perlu adanya pengenalan lebih masif ke masyarakat tentang program ini, baik melalui banner atau iklan di koran sehingga masyarakat lebih mengerti tentang layanan ini.

\section{G. Analisis Bauran Pemasaran Process (Proses)}

Pelaksanaan proses berobat di rawat jalan regular bergantung pada proses registrasi dan waktu tunggu. Registrasi di rawat jalan secara online memiliki performa cukup baik. Pasien dapat mendaftar secara online dan datang sesuai waktu yang ditentukan. Hanya saja, seringkali jadwal DPJP yang berubah-ubah sehingga pasien harus menyesuaikan jam praktek dari dokter tersebut.

Waktu tunggu menjadi hal krusial yang mempengaruhi performa dari proses berobat. Berdasarkan triangulasi sumber menunjukkan bahwa menurut seluruh informan proses pelayanan di rumah sakit sudah cukup bagus, karena pada umumnya tenaga kesehatan melayani sesuai dengan prosedur yang ada. Hanya saja dilihat dari segi waktu tunggu, menurut informan termasuk lama. Hal ini diakibatkan waktu pemberian pelayanan belum terkoordinasi dengan baik. Pernyataan ini didukung oleh teori yang menyatakan bahwa penyedia pelayanan kesehatan kadang kurang memperhatikan waktu pemberian pelayanan kesehatan.

Berdasarkan triangulasi metode, yang dikatakan oleh informan pihak rumah sakit memang benar bahwa mereka telah melakukan pelayanan sesuai dengan prosedur yang ada. Hal ini sesuai dengan hasil observasi dimana didapatkan bahwa petugas melayani dengan sangat ramah dan sesuai dengan pelayanan yang dibutuhkan pasien.

Berdasarkan triangulasi data, menurut pendapat ahli bahwa dalam sebuah pelayanan di rumah sakit, faktor lama pelayanan dan proses melayani oleh dokter mempengaruhi penilaian pasien terhadap kinerja rumah sakit tersebut. 
Website : http://ekomaks.unmermadiun.ac.id/index.php/ekomaks

\section{Pembahasan}

Dari hasil wawancara dengan informan secara keseluruhan diperoleh informasi bahwa dalam analisis bauran pemasaran, persiapan Private Wing masih diperlukan persiapan lebih matang. Hal ini disebabkan masih adanya beberapa variable yang belum dipersiapkan dengan baik, yaitu variabel place, promotion dan people.

Kendala akses masih menjadi permasalahan dalam memberikan layanan. Masyarakat menjadi tidak tertarik dalam berobat, apabila akses menuju tempat layanan terlalu sulit. Minimal, terdapat fasilitas umum yang dapat menjangkau tempat tujuan dengan mudah.

Selanjutnya, perlu dipikirkan dalam mekanisme pemberian gaji untuk dokter spesialis, dokter spesialis adalah objek utama dalam pemberian Private Wing. Apabila pemberian insentif tidak dipenuhi maksimal, maka dokter spesialis tidak memberikan pelayanan secara maksimal (Stanowski et al., 2015).

Rumah Sakit Nasional Diponegoro adalah rumah sakit publik yang dimiliki oleh Universitas Diponegoro, hal ini menjadi penguat bagi rumah sakit nasional diponegoro karena memiliki customer tetap dafri internal Universitas Diponegoro, tak terkecuali civitas akademika hingga keluarga. Namun, perlu menjadi perhatian bahwa Private Wing adalah usaha dalam mengembangkan pasar. RSND memiliki jejaring FKTP yang luas dan ditopang FKTP yang menjadi sarana Pendidikan mahasiswa fakultas kedokteran, sehingga dapat menjadi media pengenalan Rumah Sakit Nasional Diponegoro. Selain itu, pelaksanaan pengenalan via webinar menggandeng dokter spesialis, bisa bersifat awam maupun medis, dalam rangka lebih dekat mengenalkan private wing. Hal-hal ini dapat ditempuh dalam mengembangkan media promosi apabila dianggap promosi secara terbuka dianggap tabu.

\section{KESIMPULAN DAN SARAN}

Berdasarkan hasil penelitian yang dilakukan didapatkan kesimpulan bahwa secara keseluruhan persiapan Private Wing di RSND masih memperlukan pembenahan, yang terlihat dari beberapa variable marketing mix sebagai berikut :

1. RSND memperluas pasar kepada pasien pembayaran out of pocket dengan membangun Private Wing

2. Private Wing adalah produk optimalisasi poliklinik regular diluar jam kerja

3. Harga yang ditetapkan untuk Private Wing dapat lebih diterima oleh masyarakat luas

4. Lokasi menjadi kelemahan dalam pembangunan Private Wing, diperlukan kerja sama lintas sektor dalam memberikan kemudahan dan keamanan akses, terutama dimalam hari

5. Terdapat 2 opsi pembangunan Private Wing, namun untuk optimalisasi dan penerapan one stop service dapat menggunakan bangunan poli rawat jalan reguler dengan diferensiasi jam kerja

6. RSND memiliki sumber daya manusia yang secara kuantitatif dan kualitatif cukup, namun perlu memperhatikan aturan keuangan dalam memberikan insentif yang layak kepada tenaga kesehatan

7. Promosi perlu dilakukan secara masif, total pasien umum sebesar $10 \%$ perlu menjadi perhatian, dapat mengoptimalkan jejaring promosi yang dimiliki

8. Proses pengobatan yang berjalan selama ini sudah berjalan cukup baik, namun perlu dilakukan evaluasi dalam waktu tunggu dokter dan farmasi.

Saran dalam penelitian ini :

1. Unsur yang tercakup dalam marketing mix pelayanan Private Wing, mampu memiliki kepekaan dalam rasa kompetitif dengan rumah sakit lain

2. Tanggung jawab dalam menyampaikan layanan Private Wing, tidak serta merta tanggung jawab humas, namun adalah proses marketing mix yang dijalani oleh semua unsur, sehingga semua unsur di rumah sakit dapat menjalankan sesuai tupoksi

3. Direksi dan manajer perlu melakukan advokasi kepada pihak universitas, dalam rangka membangun fleksibilitas rumah sakit, sehingga dalam pembangunan Private Wing tidak terbentur aturan birokrasi Perguruan Tinggi

\section{DAFTAR PUSTAKA}

Abdurrahman, M. F., Daryanto, A., \& Nuraisyah, A. (2021). Coffee to Go Marketing Mix (7P) Analysis to Improve Customer Satisfaction (Case Study Katuhu Coffee). Business Review and Case Studies, 2(2), 70-79. https://doi.org/10.17358/brcs.2.2.70

Anjani, H. D., Irham, I., \& Waluyati, L. R. (2018). Relationship of 7P Marketing Mix and Consumers' Loyalty in Traditional Market. Agro Ekonomi, 29(2), 261-273.

Benyamin, A. P. (2019). Strategi Bauran Pemasaran (Marketing Mix Strategy) Di Pasarkita Pamulang. Jurnal Pemasaran Kompetitif, 2 (3), 1. https://doi.org/10.32493/jpkpk.v2i3.2836

Christian A.D, S. (2016). Bauran Pemasaran (Marketing Mix) Pengaruhnya terhadap Loyalitas Konsumen pada Fresh Mart Bahu Mall Manado. Jurnal EMBA, 1(3), 71-80.

Dr. Muhammad Tariq Khan. (2014). The Concept of ${ }^{\star}$ Marketing Mix'andits Elements. International Journal of Information, Business and Management, 6(2), 95-105.

Guinane, C., \& Davis, N. (2012). Improving Quality In Outpatient Services.

Išoraitė, M. (2016). Marketing Mix Theoretical Aspects. International Journal of Research -GRANTHAALAYAH, 4(6), $25-37$. 


\section{Website : http://ekomaks.unmermadiun.ac.id/index.php/ekomaks}

https://doi.org/10.29121/granthaalayah.v4.i6.2016.2633

Kukanja, M., Gomezelj Omerzel, D., \& Kodrič, B. (2017). Ensuring restaurant quality and guests' loyalty: an integrative model based on marketing (7P) approach. Total Quality Management and Business Excellence, 28(13-14), 1509-1525. https://doi.org/10.1080/14783363.2016.1150172

Kushwaha, G. S., \& Agrawal, S. R. (2015). An Indian customer surrounding 7P[U+05F3]s of service marketing. Journal of Retailing and Consumer Services, 22, 85-95. https://doi.org/10.1016/j.jretconser.2014.10.006

Marques, A., Lacerda, D. P., Camargo, L. F. R., \& Teixeira, R. (2014). Exploring the relationship between marketing and operations: Neural network analysis of marketing decision impacts on delivery performance. International Journal of Production Economics, 153(October), 178-190. https://doi.org/10.1016/j.ijpe.2014.02.020

MedPAC. (2018). Hospital inpatient and outpatient services. Report to the Congress: Medicare Payment Policy, 63-91.

Nugroho, R., \& Japarianto, E. (2013). Pengaruh People, Physical Evidence, Product , Promotion, Coffee Cozies Surabaya. Jurnal Manajemen Pemasaran Petra, 1(2), 1-9. https://media.neliti.com/media/publications/134687-ID-pengaruh-people-physical-evidence-produc.pdf

Palmer, C., \& Bolderston, A. (2006). A Brief Introduction to Qualitative Research. Canadian Journal of Medical Radiation Technology, 37(1), 16-19. https://doi.org/10.1016/s0820-5930(09)60112-2

Undang-undang Republik Indonesia Nomor 44 Tahun 2009 Tentang Rumah Sakit, (2009).

Pratami, D. A., Taufikkurohman, \& Djoko, S. (2016). Evaluasi Kinerja Rumah Sakit Daerah Kalisat Sebelum Dan Sesudah Badan Layanan Umum Daerah (Blud). Jurnal Magister Managemen, 1(1), 43-56.

Pujiyanto, P. (2012). The Demands for Outpatient Care in Private Hospitals. Kesmas Nati Public Heal J, 7(5), 208. https://doi.org/doi:10.21109/kesmas.v7i5.42

Showkat, N., \& Parveen, H. (2017). In-depth Interview. Pathsala: A Gateway to Post Graduate Courses, August.

Sibarani, T., \& Riani, A. L. (2017). The Effect of Health Service Quality and Brand Image on Patients Loyalty, With Patients Satisfaction as Mediating Variable (A Study in Vip Ward Of Prof. Dr R Soeharso Ortopedics Hospital In Surakarta). Sebelas Maret Business Review, 2(1), 25-42. https://doi.org/10.20961/smbr.v2i1.12436

Stanowski, A. C., Simpson, K., \& White, A. (2015). Pay for performance: Are hospitals becoming more efficient in improving their patient experience? Journal of Healthcare Management, 60(4), 268-284. https://doi.org/10.1097/00115514-201507000-00008

Thabit, T. H., \& Raewf, M. (2018). The Evaluation of Marketing Mix Elements: A Case Study. International Journal of Social Sciences \& Educational Studies, 4(4), 100-109. https://doi.org/10.23918/ijsses.v4i4p100

Widajat, R. (2021). Being a Sustainable \& Ubiquitous Indonesia Hospital: Membangun Rumah Sakit Khas Indonesia di Tengah dan Pasca-Pandemi Covid-19. Gramedia Pustaka Utama.

Yarimoglu, E. K. (2014). A Review on Dimensions of Service Quality Models. Journal of Marketing Management, 2(2), $79-93$. 